\title{
Uteroglobin-related protein 1 and severity of inhalation injury
}

\author{
G Friedman $^{1 *}$, SF Henrich ${ }^{1}$, TH Rech ${ }^{2}$, F Dal Pizzol ${ }^{3}$ \\ From ESICM LIVES 2015 \\ Berlin, Germany. 3-7 October 2015
}

\section{Introduction}

Burns are a major global public health problem. It is estimated that over 300 million burn victims die each year worldwide. Most accidents are domestic or on workplace and involve mainly women and children. With the advances made in the care of burned patients, the mortality has decreased in recent years and the inhalation injury has become the leading cause of death in these patients. Mortality associated to smoke inhalation alone may be low $(0-11 \%)$, but the inhalation combined with skin burns can reach $90 \%$. Uteroglobin-related protein 1 (UGRP1) is a secretory protein expressed in the airways, and speculated to have anti-inflammatory activity.

\section{Objectives}

To evaluate if UGRP1 plasma levels are related to the severity of inhalation injury.

\section{Methods}

Observational study, mechanically ventilated patients admitted to the Intensive Care Unit of the Hospital de Clinicas de Porto Alegre, victims of a great fire in January 2013 in the city of Santa Maria, state of Rio Grande do Sul, Brazil.

\section{Results}

We included 16 patients (age: $23 \pm 5$ yrs), with inhalation injury: grades $1(\mathrm{n}=3), 2(\mathrm{n}=4)$, and $3(\mathrm{n}=9)$. UGRP1 levels were significantly related to the severity of inhalation (Grade $10.389 \pm 0.053 \mathrm{mcg}$ vs. grade 2 $0.474 \pm .0423 \mathrm{mcg}$ vs grade $30.580 \pm 0.094 \mathrm{mcg}$; $\mathrm{p}=0.007)$.

'Universidade Federal do Rio Grande do Sul, PPG Ciências Pneumológicas, Porto Alegre, Brazil

Full list of author information is available at the end of the article

\section{Conclusions}

Uteroglobin-related protein 1 levels are significantly increased in patients with inhalation injury and associated to the injury severity, particularly in those with grade 3 inhalation injury.

\section{Grant Acknowledgment}

Universidade do Extremo Sul Catarinense

\section{Authors' details}

${ }^{1}$ Universidade Federal do Rio Grande do Sul, PPG Ciências Pneumológicas, Porto Alegre, Brazil. ${ }^{2}$ Universidade Federal do Rio Grande do Sul, Hospital de Clínicas de Porto Alegre, Porto Alegre, Brazil. ${ }^{3}$ Universidade do Extremo Sul Catarinense, PPG Ciências da Saúde, Criciúma, Brazil.

Published: 1 October 2015

doi:10.1186/2197-425X-3-S1-A320

Cite this article as: Friedman et al:: Uteroglobin-related protein 1 and severity of inhalation injury. Intensive Care Medicine Experimental 2015 3(Suppl 1):A320.

\section{SpringerOpen $^{\odot}$}

(c) 2015 Friedman et al.; This is an Open Access article distributed under the terms of the Creative Commons Attribution License (http:// creativecommons.org/licenses/by/4.0), which permits unrestricted use, distribution, and reproduction in any medium, provided the original work is properly cited.

Submit your manuscript to a SpringerOpen ${ }^{\circ}$ journal and benefit from:

- Convenient online submission

- Rigorous peer review

- Immediate publication on acceptance

- Open access: articles freely available online

- High visibility within the field

- Retaining the copyright to your article

Submit your next manuscript at $>$ springeropen.com 